\title{
Use in the Healthcare Industry of the Hydrogen Energy Produced by Solid Hydrogen Sources Used in Fuel Cells
}

\author{
Elif AYDINLI [i] ${ }^{1,2}$, Haydar GÖKSU 國 ${ }^{2}$
}

\begin{abstract}
Although as an energy source today fossil fuels are used as an energy source, it should not be forgotten that fossil fuels will run out one day. In addition, it is seen that greenhouse gases which emitted from fossil fuels are seriously threatening the environment with their release into the atmosphere. We see the best example of this in today's climate changes. Therefore, sustainable and environmentally friendly energy resources are needed. One of these energy sources is also hydrogen energy which obtained from hydrogen sources. It is also important to choose an economical and easyto-use energy source for the use of hydrogen energy. Today, solid hydrogen sources are preferred for use in many areas. Solid sources of hydrogen are easy to transport, store and maintain. In addition, it provides high efficiency hydrogen and it is an environmentally friendly hydrogen source. It is possible to obtain a continuous energy source in the health sector by using solid hydrogen sources in fuel cells. It should not be forgotten how important electrical energy is, especially in hospitals.
\end{abstract}

Keywords: Solid hydrogen source; fuel cell; healthcare industry; constant energy.

\section{Yakıt Hücrelerinde Kullanılan Katı Hidrojen Kaynaklarından Üretilen Hidrojen Enerjisinin Sağlık Sektöründe Kullanımı}

ÖZ

Günümüzde fosil yakıtlar bir enerji kaynağı olarak kullanılsa da fosil yakıtların bir gün tükeneceği unutulmamalıdır. Ayrıca fosil yakıtlarla birlikte sera gazlarının atmosfere salınmasıyla çevreyi ciddi şekilde tehdit ettiği görülüyor. Bunun en güzel örneğini günümüz iklim değişikliklerinde görüyoruz. Bu nedenle sürdürülebilir ve çevre dostu enerji kaynaklarına ihtiyaç vardır. Bu enerji kaynaklarından biri de hidrojen kaynaklarından elde edilen hidrojen enerjisidir. Hidrojen enerjisinin kullanımı için ekonomik ve kullanımı kolay bir enerji kaynağı seçmek de önemlidir. Günümüzde katı hidrojen kaynakları birçok alanda kullanım için tercih edilmektedir. Katı hidrojen kaynaklarının taşınması, depolanması ve bakımı kolaydır. Ayrıca yüksek verimli hidrojen sağlar ve çevre dostu bir hidrojen kaynağıdır. Yakıt hücrelerinde katı hidrojen kaynakları kullanılarak sağlık sektöründe sürekli bir enerji kaynağı elde etmek mümkündür. Özellikle hastanelerde elektrik enerjisinin ne kadar önemli olduğu unutulmamalıdır.

Anahtar Kelimeler: Katı hidrojen kaynağı; yakıt hücresi; sağlık endüstrisi; sürekli enerji.

1 Program of Natural, Herbal and Cosmetic Products, Institute of Health Sciences, Düzce University, Düzce 81620, Turkey

2 Kaynasli Vocational College, Düzce University, Düzce 81900, Turkey

Corresponding Author: Haydar GOKSU, e-mail: haydargoksu@duzce.edu.tr

Received: 21.02.21, Kabul Tarihi / Accepted: 15.05.21

\section{INTRODUCTION}

The hydrogen is an economical and environmentally friendly energy source. However, the biggest problem is the storage and transportation of hydrogen. Table 1 shows that hydrogen is more environmentally friendly than other energy sources (1).

Transport of hydrogen in gaseous form is risky and requires special systems for its use, which increases the cost $(2,3)$. It is even possible to store hydrogen on the surface of carbon-based materials such as carbon nanotubes (CNT). Low temperatures are required to maintain this hydrogen source. However, this method is costly and there is a loss of energy (4).

Another way of storing hydrogen gas is to turn it into a cryogenic liquid form. This process is also costly. Because hydrogen, which is brought into cryogenic liquid form at a temperature below $-252.9^{\circ} \mathrm{C}$, and must be kept at this temperature. The slightest change in temperature causes hydrogen to be in gas form and lose energy (5). 
Isopropyl alcohol $(6,7)$, glycerol (8-10) etc. alcohols are also used as sources of liquid hydrogen. However, high temperatures and some chemical materials are required to obtain hydrogen gas from such alcohols (11-13). For example,

isopropyl alcohol has been used as a hydrogen source in the transfer hydrogenation of acetophenone in the literature. Acetone is obtained by dehydrogenation of isopropyl alcohol. This molecule is used as a solvent both in industry and laboratories. In another study, glycerol was used as a hydrogen source in the hydrogenation of nitroarenes to amines. Glycerol is used both in the cosmetics industry and as a serious waste in the same sector. The use of this waste as an environmentally friendly energy source is indisputable (14).

Table 1. Environmental impact of energy resources

\begin{tabular}{|c|c|c|c|}
\hline & $\begin{array}{l}\text { Environmental } \\
\text { impact factor } \\
(\text { EIF })^{\mathrm{a}}\end{array}$ & $\begin{array}{l}\text { Green } \\
\text { influence } \\
\text { factor } \\
(\mathbf{G F})^{\mathbf{b}}\end{array}$ & $\begin{array}{l}\text { Hydrogen } \\
\text { content } \\
\text { factor } \\
(\text { HCF })^{\mathrm{c}}\end{array}$ \\
\hline Coal & 3.6 & 0 & 0 \\
\hline Oil & 3.0 & 0.15 & 0.2 \\
\hline Natural gas & 2.7 & 0.25 & 0.3 \\
\hline Hydrogen & 0 & 1 & 1 \\
\hline
\end{tabular}

The hydrogen production from methane with the steam conversion process is also a method used in industry. However, since this process requires high temperatures, its usage area is limited and costly. In addition, supply, transportation and storage of methane gas requires a process as demanding as the hydrogen gas obtained (equation 1) $(15,16)$.

$$
\begin{aligned}
& \mathrm{CH}_{4(\mathrm{~g})}+\mathrm{H}_{2} \mathrm{O} \stackrel{\triangle}{\longrightarrow} \mathrm{CO}_{(\mathrm{g})}+3 \mathrm{H}_{2(\mathrm{~g})} \\
& \text { Equaion } 1
\end{aligned}
$$

Today, the most popular and low-cost hydrogen source are solid hydrogen sources. Solid sources of hydrogen often interact with water and undergo dehydrogenation to produce hydrogen. Effective sources of solid hydrogen include metal hydrides (MH) $(17,18)$, sodium borohydride (NaBH4) (19), ammonia borane $(\mathrm{AB})(20)$ ve and dimethyl ammonia borane (DMAB)(21).

Energy densities of stored hydrogen in different types are shown in Table 2.

Table 2. Different types of storage and energy content of hydrogen

\begin{tabular}{cc}
\hline Storage Type & Energy Density $\left(\mathbf{M J} / \mathbf{m}^{3}\right)$ \\
\hline Hydrogen Gas $(0.1 \mathrm{MPa})$ & 10 \\
Liquid Hydrogen & 8700 \\
Metal Hydrides & 11450 \\
\hline
\end{tabular}

These results demonstrate the importance of solid hydrogen sources (22).

Solid sources of hydrogen have some advantages:

- Absence of storage problem,
- Being portable,

- Being stable,

- It is stable temperature range is wide,

- High hydrogen capacity,

- Ease of use.

Dehydrogenation of sodium borohydride (equation 2):

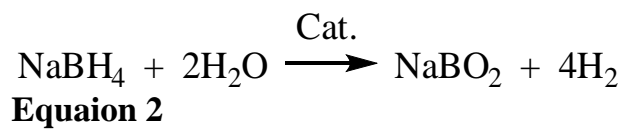

As above, dehydrogenation of solid hydrogen sources in water at room temperature and under the action of a catalyst is possible. There have been many studies on this subject in recent years (23-25). Especially, by synthesizing different catalyst structures, the dehydrogenation capacities on solid hydrogen sources are investigated. Among the catalysts produced are those used industrially.

In recent years, serious studies have been carried out on fuel cells in the scientific community. The aim is to obtain a technological and sustainable energy. In addition, it is possible to minimize foreign dependency with this technology. Fuel cells generate energy by reacting hydrogen, which is obtained from oil, coal and many waste materials through a converter, with oxygen. Fuel cells have some advantages: i) higher efficiency than fossil fuels, ii) environmentally friendly technology, iii) minimum risk, iv) ability to generate electrical energy as long as fuel support is provided, v) energy support the availability of heat.

Fuel cells can be used in land, sea and space vehicles, technological devices, houses, industry, public and private institutions, especially hospitals.

It is important to use the correct hydrogen source in fuel cells, which is today's technology. In fuel cells, it is possible to obtain hydrogen in a more practical way by using solid hydrogen sources instead of hydrogen production through difficult processes or using hydrogen gas directly. It is possible to use this energy as a continuous energy source in the health sector, especially in hospitals, by transforming this hydrogen which produced by a practical method into electrical energy and even by providing energy transformations of the heat released. There are some reasons why hospitals need constant energy supply:

- Medical imaging systems (x-ray, computed tomography, magnetic resonance imaging, angiography, ultrasonography-doppler, film processing devices, radiation detectors),

- Operating room and breathing devices (defibrillator, ventilator, electrocautery, operating lights, heart lung pump, heater-cooler, blood warmers, surgical aspirator, auto transfusion devices)

Biochemistry, molecular biology, hematology, genetics, and microbiology devices (autoanalyzer, blood analysis, centrifuge, blood and blood products storage, apheresis, automatic sequencing, PCR (polymerase chain reaction), flow cytometry devices, DNA chips reading and evaluation units) 
- Biological signal monitoring devices (EKG, EMG, ERG, oxygen saturation devices and bedside monitors)

- Radiotherapy systems (intracavitary, simulators, Co-60 teletherapy devices)

- $\quad$ Physical therapy devices

- Optical medical devices (endoscopes, microscopes, light sources, lasers, otoscopes, and ophthalmoscopes)

- Sterilizers and oven devices (autoclave, oven, gas sterilizers)

Considering that every device needed in descriptive, curative, and preventive services in hospitals requires energy, it becomes clear how important the continuous energy source is.

\section{CONCLUSION}

With the increase in the world population, energy consumption is also increasing rapidly. Considering that fossil fuels, which are currently used as an energy source, will end one day, efforts to find a permanent and environmentally friendly energy source continue. However, in this process, hydrogen can be considered as the most efficient and applicable energy source. Hydrogen is an ideal energy carrier due to its storability, environmental friendliness, high calorific value and cost effectiveness. Compared to other fuels, it can be converted into different energy forms with higher efficiency. One of these forms are solid sources of hydrogen. Solid hydrogen sources are preferred especially in transportation, industry, space rockets, oil production, heating and cooling systems, heat, and electricity storage systems. It is very advantageous in terms of stability of solid hydrogen sources at different temperatures and transportation / storage costs. A cleaner energy can be obtained by using solid hydrogen sources in fuel cells. In addition, the fact that it is an easy-to-use and continuous energy source allows fuel cells to be used in the health sector. The value of fuel cells increases even more, especially in hospitals, considering the devices that operate on electrical energy and their importance.

\section{ACKNOWLEDGEMENTS}

We would like to thank Duzce University for providing infrastructure support in our studies.

Authors's Contributions: Idea/Concept: H.G.; Design: H.G.; Data Collection and/or Processing: H.G., E.A.; Literature Review: H.G., E.A.; Writing the Article: H.G., E.A.; Critical Review: H.G., E.A.

\section{KAYNAKLAR}

1. Dincer I, Acar C. Review and evaluation of hydrogen production methods for better sustainability. International Journal of Hydrogen Energy. 2015; 40(34): 11094-111.

2. Pique S, Weinberger B, De-Dianous V, Debray B. Comparative study of regulations, codes and standards and practices on hydrogen fuelling stations. International Journal of Hydrogen Energy. 2017; 42(11): 7429-39.

3. Loisel R, Baranger L, Chemouri N, Spinu S, Pardo S. Economic evaluation of hybrid off-shore wind power and hydrogen storage system. International Journal of Hydrogen Energy. 2015; 40(21): 6727-39.

4. Gao S, Wang X, Liu H, He T, Wang Y, Li S, et al. Effects of nano-composites (FeB, FeB/CNTs) on hydrogen storage properties of $\mathrm{MgH} 2$. Journal of Power Sources. 2019; 438: 227006.

5. Sakintuna B, Lamari-Darkrim F, Hirscher M. Metal hydride materials for solid hydrogen storage: A review. International Journal of Hydrogen Energy. 2007; 32(9): 1121-40.

6. Li Z, Zhao D, Luo J. Nanoporous palladium catalyst for the reduction of aromatic nitro compounds with silane/alcohol system as the hydrogen source. Inorganic Chemistry Communications. 2019; 100: 15 .

7. Daryakenari AA, Mosallanejad B, Zare E, Daryakenari MA, Montazeri A, Apostoluk A, et al. Highly efficient electrocatalysts fabricated via electrophoretic deposition for alcohol oxidation, oxygen reduction, hydrogen evolution, and oxygen evolution reactions. International Journal of Hydrogen Energy. 2021; 46(10): 7263-83.

8. Rocha DHD, de Souza TAZ, Coronado CJR, Silveira JL, Silva RJ. Exergoenvironmental analysis of hydrogen production through glycerol steam reforming. International Journal of Hydrogen Energy. 2021; 46(1): 1385-402.

9. Chen Y, Yin Y, Wang J. Comparison of fermentative hydrogen production from glycerol using immobilized and suspended mixed cultures. International Journal of Hydrogen Energy. 2021; 46(13): 8986-94.

10. Wang K, Heltzel J, Sandefur E, Culley K, Lemcoff G, Voutchkova-Kostal A. Transfer hydrogenation of levulinic acid from glycerol and ethanol using watersoluble iridium $\mathrm{N}$-heterocyclic carbene complexes. Journal of Organometallic Chemistry. 2020; 919: 121310.

11. Adair GRA, Williams JMJ. Oxidant-free oxidation: ruthenium catalysed dehydrogenation of alcohols. Tetrahedron Lett. 2005; 46(47): 8233-5.

12. Nielsen M, Kammer A, Cozzula D, Junge H, Gladiali S, Beller M. Efficient Hydrogen Production from Alcohols under Mild Reaction Conditions. Angew Chem-Int Edit. 2011; 50(41): 9593-7.

13. Ligthart GBWL, Meijer RH, Donners MPJ, Meuldijk J, Vekemans JAJM, Hulshof LA. Highly sustainable catalytic dehydrogenation of alcohols with evolution of hydrogen gas. Tetrahedron Lett. 2003; 44(7): 1507-9.

14. Sudhakar M, Naresh G, Rambabu G, Anjaneyulu C, Padmasri AH, Kantam ML, et al. Crude bio-glycerol as a hydrogen source for the selective hydrogenation of aromatic nitro compounds over $\mathrm{Ru} / \mathrm{MgLaO}$ catalyst. Catalysis Communications. 2016; 74: 91-4.

15. Makhov GA, Bazhin NM. Methane emission from lakes. Chemosphere. 1999; 38(6): 1453-9.

16. Boubenia A, Hafaifa A, Kouzou A, Mohammedi K, Becherif M. Carbone dioxide capture and utilization in gas turbine plants via the integration of power to gas. Petroleum. 2017; 3(1): 127-37.

17. Chen K, Yuan D, Zhao Y. Review of optical hydrogen sensors based on metal hydrides: Recent 
developments and challenges. Optics \& Laser Technology. 2021; 137: 106808.

18. Malleswararao K, Aswin N, Srinivasa Murthy S, Dutta P. Studies on a dynamically coupled multifunctional metal hydride thermal battery. Journal of Alloys and Compounds. 2021; 866: 158979.

19. Goksu H. Recyclable aluminium oxy-hydroxide supported $\mathrm{Pd}$ nanoparticles for selective hydrogenation of nitro compounds via sodium borohydride hydrolysis. New J Chem. 2015; 39(11): 8498-504.

20. Deka JR, Saikia D, Lu NF, Chen KT, Kao HM, Yang YC. Space confined synthesis of highly dispersed bimetallic $\mathrm{CoCu}$ nanoparticles as effective catalysts for ammonia borane dehydrogenation and 4nitrophenol reduction. Appl Surf Sci. 2021; 538: 15.

21. Goksu H, Yildiz Y, Celik B, Yazici M, Kilbas B, Sen F. Eco-friendly hydrogenation of aromatic aldehyde compounds by tandem dehydrogenation of dimethylamine-borane in the presence of a reduced graphene oxide furnished platinum nanocatalyst. Catal Sci Technol. 2016; 6(7): 2318-24.

22. Sørensen B. Preface to first edition. In: Sørensen B, editor. Hydrogen and Fuel Cells (Second Edition). Boston: Academic Press; 2012. p. vi.

23. Debnath T, Ash T, Sarkar S, Ghosh A, Das AK. Exploration of $\mathrm{M}(100)-2 \times 1 \quad(\mathrm{M}=\mathrm{Si}, \mathrm{Ge})$ surface termination through hydrogen passivation using ethane and ammonia-borane derivatives: A theoretical approach. Journal of Molecular Graphics and Modelling. 2019; 87: 11-21.

24. Abdelhamid HN. Dehydrogenation of sodium borohydride using cobalt embedded zeolitic imidazolate frameworks. Journal of Solid State Chemistry. 2021; 297: 122034.

25. Zhang S, Wang L, Tai Y-L, Teng Y-L, Zhao J, Zhu $\mathrm{W}$, et al. Metal carbonates-induced solution-free dehydrogenation of alkaline earth metal hydrides at room temperature. Journal of Solid State Chemistry. 2020; 289: 121485. 